\title{
MENINGKATKAN PERILAKU HIDUP SEHAT TERHADAP MASYARAKAT DESA SUKARATU KECAMATAN MAJASARI DI MASA PANDEMI COVID-19
}

\author{
Sri Ndaru Arthawati \\ Fakultas Ekonomi dan Bisnis, Universitas Sultan Ageng Tirtayasa, Jalan Raya Jakarta KM. 4, Banten \\ Email: arthawatisri@gmail.com
}

\begin{abstract}
Patterns of healthy living behavior, namely all health rules that are applied with awareness from within oneself without coercion to take health action against himself, his family, or the surrounding environment. Prevention is better than cure is the foundation of health which forms the basis of a healthy life implementation program. During the Covid-19 pandemic, the people of Sukaratu Village, Majasari District must be able to implement health protocols with the aim of reducing the level of Covid-19 transmission and remaining productive in carrying out daily activities. The application of social distancing and physical distancing in order to assist the government's efforts in preventing and spreading Covid-19.
\end{abstract}

Keywords: Covid-19; Healthy Living Behavior; Productive.

\begin{abstract}
ABSTRAK
Pola perilaku hidup sehat yaitu semua aturan kesehatan yang diterapkan dengan adanya kesadaran dari dalam diri sendiri tanpa adanya paksaan untuk melakukan tindakan kesehatan terhadap dirinya, keluarganya, maupun lingkungan sekitarnya. Mencegah lebih baik daripada mengobati merupakan landasan dari kesehatan yang menjadi dasar program pelaksanaan hidup sehat. Di masa pandemi Covid-19, masyarakat Desa Sukaratu Kecamatan Majasari harus dapat melaksanakan protokol kesehatan dengan tujuan untuk mengurangi tingkat penularan Covid-19 dan tetap produktif dalam menjalankan aktivitas sehari - hari. Penerapan social distancing dan physical distancing agar membantu upaya pemerintah dalam pencegahan dan penyebaran Covid-19.
\end{abstract}

Kata Kunci: Covid-19; Perilaku Hidup Sehat; Produktif.

\section{PEMBAHASAN}

Kelurahan Sukaratu yang terletak di wilayah Kecamatan Majasari Kabupaten Pandeglang Provinsi Banten, dnegan luas sekitar 379.700 Ha, memiliki batas wilayah sebelah utara Jalan Protokol/Kelurahan Seruni, sebelah selatan Kecamatan Banjar, sebelah Barat Desa Ciputri Kecamatan Kaduhejo, dan sebelah timur Kelurahan Keraton. Jumlah penduduk di Kelurahan Sukaratu yaitu 10.067 orang dengan jumlah penduduk laki - laki 5.070 dan 4.997 orang jumlah penduduk perempuan. 


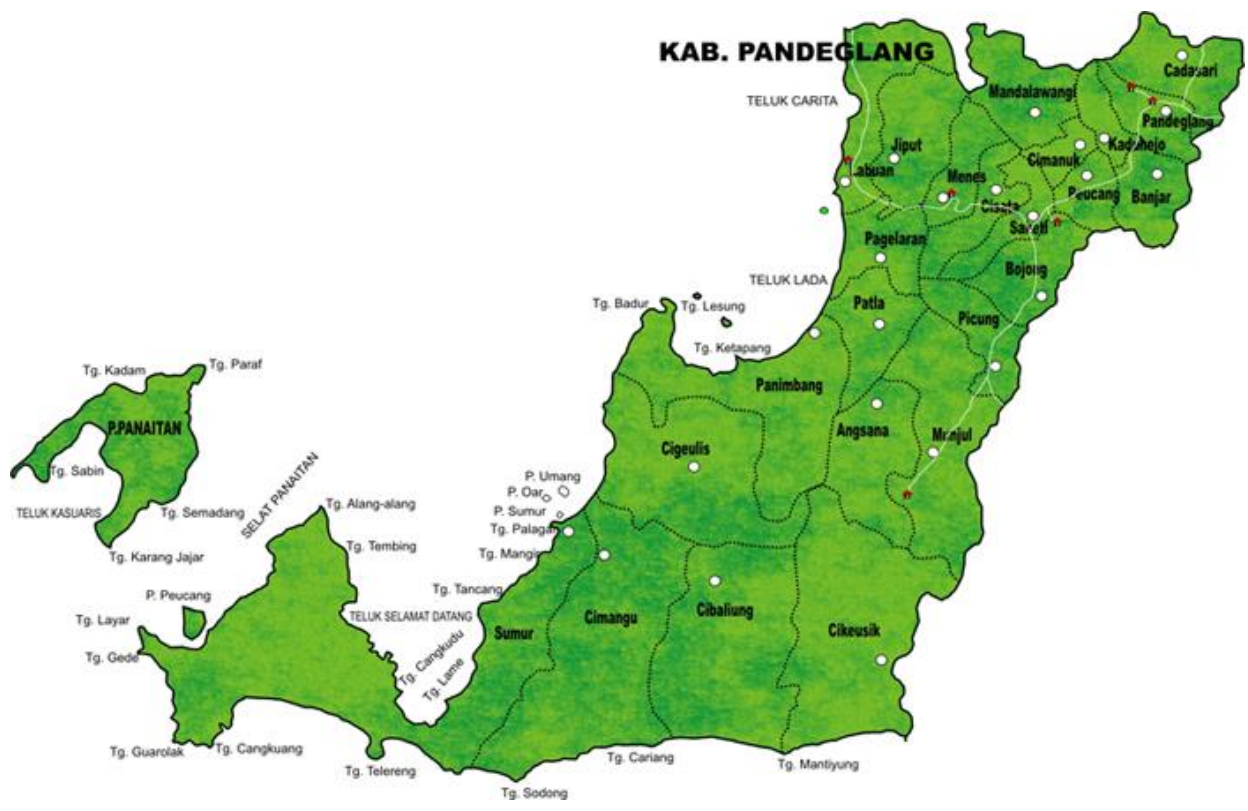

Gambar 1. Peta Wilayah Kabupaten Pandeglang

Masyarakat Desa Sukaratu di masa pandemi Covid-19 ini, harus dapat melaksanakan pola perilaku hidup sehat tetap menggunakan protokol kesehatan agar dapat menjalankan aktivitas sehari - hari dan tetap produktif. Pemerintah mengeluarkan kebijakan untuk masyarakat agar tidak berkumpul dalam jumlah yang banyak, menjaga jarak, menerapkan pola hidup yang bersih dan sehat, selalu mencuci tangan setiap selesai beraktivitas, menggunakan masker saat keluar rumah, dan tetap di rumah jika tidak ada keperluan mendesak.

Pemerintah juga mengeluarkan kebijakan baru yaitu New Normal agar masyarakat dapat beraktivitas kembali namun tetap aman dari penularan Covid-19. Akibat dari kondisi pandemi Covid-19 yang terjadi ini, maka berdampak pada pola perilaku hidup sehat masyarakat Desa Sukaratu Kecamatan Majasari agar tetap produktif dan tetap menggunakan protokol kesehatan. Covid-19 adalah penyakit menular yang disebabkan oleh SARS-COV-2, salah satu jenis corona virus. Penyakit ini mengakibatkan pandemi Coronavirus 2019 - 2020. Penderita Covid-19 dapat mengalami demam, batuk kering, kesulitan bernafas, dan sakit tenggorokan pada penderita yang paling rentan. Penyakit ini dapat berujung pada Pneumonia dan kegagalan multi-organ. Covid-19 sifatnya lebih mematikan. 
Tabel 1. Update Covid-19 Kecamatan Majasari

\begin{tabular}{l|l}
\hline ODP & 18 Kasus ODP \\
\hline PDP & 4 Kasus PDP \\
\hline Positif & 0 Kasus Positif \\
\hline Sembuh & 18 Kasus Sembuh \\
\hline Meninggal & 0 Kasus Meninggal \\
\hline
\end{tabular}

Perilaku Hidup Bersih dan Sehat adalah semua perilaku kesehatan yang dilakukan karena kesadaran pribadi sehingga keluarga dan seluruh anggotanya mampu menolong diri sendiri pada bidang kesehatan serta memiliki peran aktif dalam aktivitas masyarakat. Perilaku Hidup Bersih dan Sehat pada dasarnya merupakan sebuah upaya untuk menularkan pengalaman mengenai perilaku hidup sehat melalui individu, kelompok ataupun masyarakat luas dengan jalur - jalur komunikasi sebagai media berbagi informasi. Ada berbagai informasi yang dapat dibagikan seperti materi edukasi guna menambah pengetahuan serta meningkatkan sikap dan perilaku terkait cara hidup yang bersih dan sehat.

Perilaku hidup bersih dan sehat adalah sebuah rekayasa sosial yang bertujuan menjadikan sebanyak mungkin anggota masyarakat sebagai agen perubahan agar mampu meningkatkan kualitas perilaku sehari - hari dengan tujuan hidup bersih dan sehat. Terdapat langkah - langkah berupa edukasi melalui pendekatan pemuka atau pimpinan masyarakat, pembinaan suasana dan juga pemberdayaan masyarakat dengan tujuan kemampuan mengenal dan tahu masalah kesehatan yang ada di sekitar; terutama pada tingkatan rumah tangga sebagai awal untuk memperbaiki pola dan gaya hidup agar lebih sehat.

Tujuan utama dari kegiatan ini adalah meningkatkan kualitas kesehatan melalui proses penyadartahuan yang menjadi awal dari kontribusi individu - individu dalam menjalani perilaku kehidupan sehari - hari yang bersih dan sehat. Manfaat PHBS yang paling utama adalah terciptanya masyarakat yang sadar kesehatan dan memiliki bekal pengetahuan dan kesadaran untuk menjalani perilaku hidup yang menjaga kebersihan dan memenuhi standar kesehatan. Kegiatan penerapan pola perilaku hidup sehat di Desa Sukaratu Kabupaten Pandeglang merupakan upaya untuk meningkatkan budaya hidup sehat pada masyarakat. Kegiatan yang dilakukan mulai dari pemilahan sampah sampai sosialisasi budaya hidup sehat di lingkungan masyarakat. Tujuan dari kegiatan ini yaitu untuk menciptakan masyarakat yang sehat jasmani dan rohani. Harapannya di tengah pandem ini, masyarakat dapat tetap menjaga kesehatan nya masing - masing sehingga tetap produktif dalam kehidupan sehari - hari. 
Pelaksanaan sosialisasi protokol kesehatan tersebut dilakukan dengan cara memberikan informasi berupa poster atau gambar melalui media sosial seperti instagram, twitter, facebook dan youtube. Informasi yang disebarkan adalah terkait dengan COVID-19 serta protokol kesehatan COVID-19 seperti asal mula COVID-19, bagaimana cara penyebaran dan pencegahannya hingga penjelasan mengenai new normal. Kegiatan selanjutnya yaitu membuat video tutorial mencuci tangan yang dianjurkan oleh WHO serta membuat video demonstrasi penerapan new normal. Video tersebut akan dibagikan melalui media sosial seperti youtube dan instagram.

Selain itu, kegiatan yang dilakukan yaitu kegiatan cara pembuatan dan penyemprotan desinfektan akan dibuat dalam bentuk video tutorial agar dapat memudahkan dalam penyampaiannya dan diunggah ke youtube. Dalam pembuatan dan penyemprotan desinfektan ini menggunakan alat dan bahan yang tersedia di rumah dan mudah dijangkau. Pelaksanaan program kerja pembagian masker juga dilakukan karena perlu memperhatikan protokol kesehatan COVID-19 karena masker akan dibagikan secara langsung kepada warga. Hal-hal yang perlu diperhatikan yaitu penerapan social distancing dan physical distancing agar membantu upaya pemerintah dalam pencegahan dan penyebaran COVID-19.

Manfaat kegiatan ini secara umum adalah meningkatkan kesadaran masyarakat untuk mau menjalankan hidup bersih dan sehat. Hal tersebut agar masyarakat bisa mencegah dan menanggulangi masalah kesehatan. Selain itu, dengan menerapkan perilaku hidup bersih dan sehat masyarakat mampu menciptakan lingkungan yang sehat dan meningkatkan kualitas hidup.

Pemerintah mengeluarkan kebijakan untuk masyarakat agar tidak berkumpul dalam jumlah yang banyak, menjaga jarak, menerapkan pola hidup yang bersih dan sehat, selalu mencuci tangan setiap selesai beraktivitas, menggunakan masker saat keluar rumah, dan tetap di rumah jika tak ada keperluan mendesak. Pemerintah juga mengeluarkan kebijakan baru yaitu New Normal, agar masyarakat dapat beraktifitas kembali namun tetap aman dari penularan COVID-19. Adapun beberapa rancangan terobosan dalam kegiatan pengabdian masyarakat adalah sebagai berikut:

1. Sosialisasi tentang COVID-19 menggunakan media sosial dengan membagikan poster seputar COVID-19.

2. Membuat demonstrasi video mencuci tangan yang baik dan video penerapan new normal dan diunggah ke youtube.

3. Membuat video tutorial pembuatan desinfektan dengan bahan-bahan yang ada di rumah dan diunggah ke youtube.

4. Mengadakan webinar terkait pembelajaran di masa pandemi melalui aplikasi Zoom. 
5. Mengadakan bimbingan belajar online dengan menggunakan aplikasi Zoom.

Kepada masyarakat diharapkan dapat lebih menjaga kebersihan lingkungan demi terciptanya lingkungan yang sehat dan menjaga kesehatan keluarga dan diri sendiri, meningkatkan pelayanan kesehatan masyarakat, memberikan sosialisasi tentang kesehatan kepada masyarakat, sehingga timbul kesadaran masyarakat untuk hidup sehat, melakukan anjuran protocol kesehatan yang dianjurkan, melaksanakan new normal yang benar dan yang telah dianjurkan.

\section{METODE}

Dalam pelaksanaan kegiatan pengabdian masyarakat ini menggunakan beberapa metode antara lain: wawancara untuk mencari data profil desa, catatan lapangan untuk mengetahui secara langsung bagaimana kondisi desa Sukaratu, dokumentasi untuk merekam dan mengarsipkan seluruh kegiatan yang dilakukan, observasi, dan interview untuk memperoleh data yang dibutuhkan.

\section{HASIL DAN PEMBAHASAN}

Kegiatan yang pertama kali dilakukan sebelum memberikan pengarahan tentang perilaku hidup sehat terhadap masyarakat desa Sukaratu adalah mencari data tentang profil desa Sukaratu itu sendiri agar kegiatan yang dilaksanakan tepat sasaran. Berdasarkan hasil wawancara dan observasi didapat data sebagaui berikut:

\section{PROFIL KELURAHAN SUKARATU}

1. Kelurahan

2. Nomor Kode

3. Kecamatan

5. Kabupaten

6. Provinsi

7. Keadaan Data Bulan
: Sukaratu

: 1001

: Majasari

: Pandeglang

: Banten

: Januari 2020

\section{POTENSI UMUM}

1. Luas dan batas Wilayah
a. Luas Desa / Kelurahan
: $379.700 \mathrm{Ha}$
b. Batas Wilayah 

1). Sebelah Utara
: Jl. Protokol / Kelurahan Saruni
2). Sebelah Selatan
: Kec. Banjar
3). Sebelah Barat
: Desa Ciputri Kec.Kadu Hejo
4). Sebelah Timur
: Kelurahan Karaton / Kelurahan Kadomas

2. Kondisi Geografis
a. Ketinggian Tanah dari Permukaan laut $\quad: 250 \quad \mathrm{M}$
b. Banyaknya Curah Hujan
$: 38,4 \mathrm{~mm} / \mathrm{thn}$
c. Tofografi ( dataran rendah,tinggi,pantai ) : -
d. Suhu udara rata-rata
$: 25^{0} \mathrm{C}-28^{0} \mathrm{C}$

3. Orbitasi ( Jarak dari pusat Pemerintahan Desa/Kelurahan )
a. Jarak dari Pusat Kecamatan
: $0 \mathrm{Km}$
b. Jarak dari Pusat Kota Administratif
$:-$
c. Jarak dari Ibukota Kabupaten
: $2,8 \mathrm{Km}$
d. Jarak dari Ibukota Provinsi
: $23 \mathrm{Km}$
e. Jarak dari Ibukota Negara
: $144 \mathrm{Km}$

\section{KEPENDUDUKAN}

1. Jumlah Penduduk menurut

a. Jenis Kelamin :

$\begin{array}{llll}\text { 1) Laki-laki } & : & 5.070 & \text { Orang } \\ \text { 2) Perempuan } & : & 4.997 & \text { Orang } \\ \text { Jumlah } & : & 10.067 & \text { Orang } \\ \text { b. Kepala Keluarga } & : & 2.559 & \text { KK } \\ \text { c. Kewarganegaraan } & & & \\ \text { 1) W N I : Laki-laki } & : & 5.070 & \text { Orang } \\ \text { Perempuan } & : & 4.997 & \text { Orang } \\ \text { Jumlah } & : & 10.067 & \text { Orang } \\ \text { 2) W N A : Laki-laki } & : & & - \\ \text { Perempuan } & : & & \text { Orang } \\ \text { Jumlah } & : & & \text { Orang } \\ & & & \text { Orang }\end{array}$

\section{JUMLAH PELAYANAN MASYARAT}

1. Pelayanan Umum

2. Pelayanan Kependudukan 


\section{PENDIDIKAN}

Tabel 2. Pendidikan Umum di Desa Sukaratu

\begin{tabular}{|c|l|c|c|c|c|c|c|}
\hline \multirow{2}{*}{ No } & \multirow{2}{*}{ Jenis Pendidikan } & \multicolumn{3}{|c|}{ NEGERI } & \multicolumn{3}{c|}{ SWASTA } \\
\cline { 3 - 8 } & & Gedung & Guru & Murid & Gedung & Guru & Murid \\
\cline { 2 - 7 } & Buah & Orang & Orang & Buah & Orang & Orang \\
\hline \multirow{2}{*}{ 1. } & Kelompok & & & & & & \\
2. & Bermain & - & - & - & 2 & 5 & 50 \\
3. & T.K & - & - & - & 3 & 14 & 103 \\
4. & Sekolah Dasar & 6 & 62 & 1.024 & 1 & 5 & 90 \\
5. & SMTP & - & - & - & - & - & - \\
6. & SMTA & - & - & - & - & - & - \\
7. & A k a d e m i & - & - & - & - & - & - \\
8. & Institut/Sekolah & - & & - & - & - & - \\
& Tinggi/Unipersitas & - & - & - & - & - & - \\
& Jumlah & 6 & 62 & 1.024 & 6 & 24 & 243 \\
\hline
\end{tabular}

Tebel 3. Pendidikan Khusus

\begin{tabular}{|c|l|c|c|c|}
\hline \multirow{2}{*}{ No. } & \multicolumn{1}{|c|}{ Jenis Pendidikan } & Gedung & Guru/Pelatih & Murid \\
\cline { 2 - 5 } & & ( buah ) & ( Orang ) & ( Orang ) \\
\hline 2. & Pondok Pesantren & 19 & 33 & 429 \\
3. & Madrasah & 5 & 22 & 341 \\
& Sekolah luar Biasa: & - & - & - \\
a) SLB A & - & - & - \\
b) SLB B & - & - & - \\
c) SLB C & Sarana Pendidikan Non Formal : & - & - & - \\
& a). BLK (Balai Latihan Kerja) & - & - & - \\
& b). Kursus : & - & - & - \\
& - Bengkel Mobil / Motor & - & - & - \\
- Radio & - & - & - \\
& - Menjahit & - & - & - \\
- Salon Kecantikan & - & - & - \\
- Stir Mobil & - & - & - \\
- Lain-lain ( Mengetik, Tata Buku, & - & - & - \\
\hline
\end{tabular}




\begin{tabular}{|l|l|c|c|c|}
\hline Bahasa ) & - & - & - \\
c. PLK ( Pusat Latihan kerja ) & - & 55 & 770 \\
\hline
\end{tabular}

Pola perilaku hidup sehat yaitu semua aturan kesehatan yang diterapkan dengan adanya kesadaran dari dalam diri sendiri tanpa adanya paksaan untuk melakukan tindakan kesehatan terhadap dirinya, keluarganya, maupun lingkungan sekitarnya. Mencegah lebih baik daripada mengobati merupakan landasan dari kesehatan yang menjadi dasar program pelaksanaan hidup sehat. Di masa pandemi Covid-19, masyarakat Desa Sukaratu Kecamatan Majasari harus dapat melaksanakan protokol kesehatan dengan tujuan untuk mengurangi tingkat penularan Covid-19 dan tetap produktif dalam menjalankan aktivitas sehari - hari. Penerapan social distancing dan physical distancing agar membantu upaya pemerintah dalam pencegahan dan penyebaran Covid-19.

Pada dasarnya setiap orang pasti ingin memiliki tubuh yang sehat, namun seiring dengan berkembangnya zaman dan kesibukan, terkadang kita mejadi lupa menjalani pola hidup sehat guna menjaga kesehatan. Hasilnya, kita menjadi terjangkit berbagai macam penyakit dan tidak jarang penyakit tersebut adalah penyakit serius. Jika kita sudah terkena penyakit, maka akan ada banyak hal yang merepotkan. Kita harus mengeluarkan budget untuk pergi ke dokter dan membeli obat, aktifitas kita menjadi tertunda, dan kita akan merepotkan orang lain karena kita pasti membutuhkan bantuan sehingga mereka harus merawat kita. Ini hanya sebagian hal dari banyaknya kerepotan yang terjadi saat kita sakit. Untuk menghindari hal tersebut, hal yang paling mudah kita lakukan adalah dengan menjalani pola hidup sehat.

Kesehatan adalah dambaan kita semua. Untuk hidup sehat tentunya akan menjalankan sebuah aktifitas rutin dengan memperhatikan gaya hidup sehat. Kekayaan lahir dan batin tidak akan ada artinya bila kita masih terjebak dalam kondisi atau situasi sakit baik itu karena virus penyakit ataupun karena tingkah laku yang tidak memperhatikan kondisi badan. Pola hidup sehat adalah upaya seseorang untuk menjaga tubuhnya agar tetap sehat. Pola hidup sehat dapat dilakukan dengan cara mengonsumsi makanan bergizi, olahraga secara rutin, dan istirahat yang cukup. Kebanyakan dari kita menganggap bahwa pola hidup sehat adalah pola hidup yang sulit untuk dijalani. Namun sebenarnya, ada banyak cara yang mudah dilakukan untuk menjaga diri kita tetap sehat.

Pola hidup sehat selalu berhubungan dengan faktor makanan yang menyehatkan serta menjauhi dari pola makanan tidak sehat yang nantinya akan menyebabkan harihari kita menjadi suram karena timbul penyakit. Selain dari aspek makanan yang sehat juga bergizi satu hal yang tidak boleh kita lupakan adalah menjaga kondisi tubuh supaya tetap bugar 
dengan olahraga yang teratur dan menghindari tubuh kecapekan sehingga pikiran kita stress. Dengan selalu memperhatikan pola hidup sehat semoga kita selalu dalam keadaan sehat. Dapat menjalani kehidupan ini dengan penuh makna bersama keluarga atau lingkungan sekitar kita. Tujuan atau manfaat dari pola hidup sehat tentunya untuk menjaga kesehatan tubuh supaya tidak mudah sakit. Tapi menerapkan pola hidup sehat memiliki beberapa tujuan juga, misalnya; untuk mendapatkan kesehatan jasmani dan rohani dapat selalu terjaga dan supaya memiliki kesehatan mental yang stabil sehingga tidak mudah depresi ataupun stress.

Pengabdian kepada masyarakat ini dilaksanakan di Desa Sukaratu Kecamatan Majasari Kabupaten Pandeglang. Hasil yang dicapai dari kegiatan ini antara lain :

1. Meningkatkan perilaku hidup sehat, menjaga kesehatan serta menjaga kebersihan lingkungan hidup, dan tetap produktif di masa pandemi Covid-19.

2. Mengedukasi masyarakat mengenai bahaya Covid-19 dan mendorong masyarakat dalam rangka pencegahan dan penanggulangan Covid-19.

3. Berpartisipasi dalam membantu Pemerintah untuk menerapkan protokol Covid-19 di Lingkungan Desa Sukaratu Kecamatan Majasari Kabupaten Pandeglang.

4. danya penurunan tingkat penularan Covid-19, akibat dari kesadaran masyarakat Desa Sukaratu yang telah menerapkan protokol kesehatan.

5. Memutuskan rantai penularan Covid-19 terhadap masyarakat di Desa Sukaratu Kecamatan Majasari Kabupaten Pandeglang.

6. Masyarakat dapat lebih menjaga kebersihan lingkungan demi terciptanya lingkungan yang sehat dan menjaga kesehatan keluarga dan diri sendiri.

7. Meningkatkan pelayanan kesehatan di Desa Sukaratu Kecamatan Majasari Kabupaten Pandeglang.

8. Memberikan sosialisasi tentang kesehatan kepada masyarakat sehingga timbul kesadaran masyarakat untuk menerapkan pola perilaku hidup sehat.

9. Melaksanakan new normal dengan benar sesuai dengan Peraturan Pemerintah yang telah ditetapkan.

Hidup sehat adalah hidup yang bebas dari semua masalah rohani (mental) ataupun masalah jasmani (fisik). Hidup sehat bisa diartikan sebagai seseorang yang hidup sehat secara fisik dan psikis tanpa ada masalah kesehatan sedikitpun. Seakan sudah menjadi tren di zaman sekarang, hidup sehat menjadi sebuah hal penting yang harus dilakukan. Sebab memiliki tubuh yang sehat harus diawali dengan hidup sehat dan bersih sehingga tubuh kita akan terbebas dari penyakit. Mulai sekarang sudah saatnya kita untuk memulai hidup sehat.

Saat ini masih banyak orang yang belum sadar betapa pentingnya hidup sehat untuk kehidupan sehari-hari. Memiliki tubuh yang sehat tentu akan menunjang aktivitas kita sehari- 
hari. Bayangkan saja jika kita memiliki penyakit yang disebabkan oleh gaya hidup yang tidak sehat tentu akan merugikan diri sendiri dan juga keluarga. Sebab, aktivitas akan terganggu karena kita sakit bahkan akan banyak biaya yang keluar untuk pengobatan. Oleh sebab itu kita harus sudah sadar betapa pentingnya menjaga kesehatan. Hidup sehat bisa dimulai dari diri sendiri dengan mengurangi kebiasaan yang tidak baik untuk kesehatan. mulai sekarang sudah saatnya kita untuk memulai hidup sehat tanpa diabetes, hidup sehat tanpa merokok, hidup sehat tanpa obat dan hidup sehat bebas kanker. ayo mulai hidup sehat sejak remaja sehingga bisa hidup sehat hingga lansia.

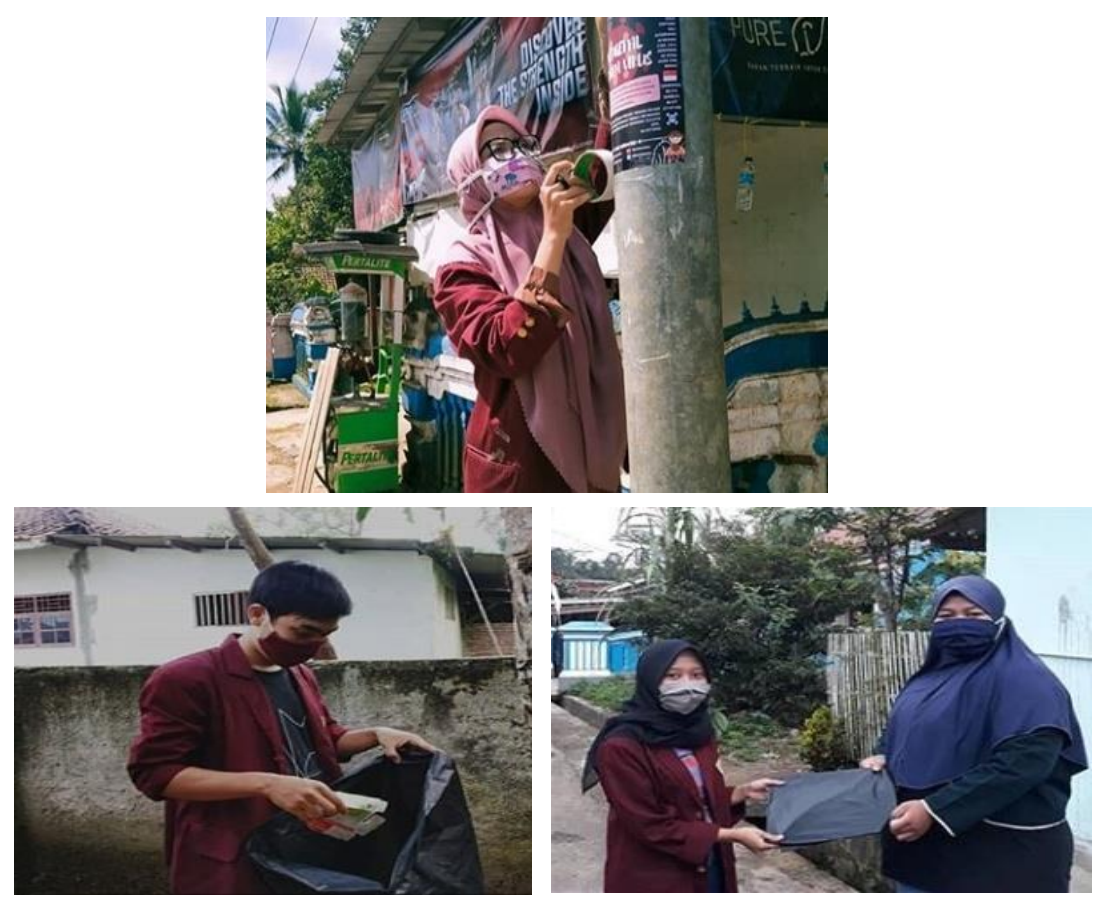

\section{Gambar 2. Kegiatan Pola Perilaku Hidup Sehat di Desa Sukaratu Pandeglang}

\section{KESIMPULAN}

Kegiatan pengabdian masyarakat ini dilaksanakan di Desa Sukaratu Kecamatan Majasari Kabupaten Pandeglang. Berdasarkan kondisi lapangan yang diperoleh antara lain:

1. Kendala yang muncul adalah batasan untuk mengikuti protokol kesehatan.

2. Masyarakat Desa Sukaratu sudah dapat melaksanakan protokol kesehatan di masa pandemi Covid-19.

3. Masyarakat dapat memahami penerapan protokol kesehatan dalam kehidupan sehari - hari sehingga dapat membentuk kepribadian yang mandiri dan bertanggungjawab terhadap kesehatan. 
4. Dengan adanya kegiatan sosialisasi/penyuluhan ini dapat meningkatkan ilmu pengetahuan masyarakat di Desa Sukaratu.

\section{DAFTAR PUSTAKA}

Gubernur Banten. (2020). Surat Keterangan Gubernur Banten No 443/Kep.209-HUK/2020 Tentang Penetapan PSBB di Banten dalam Rangka Percepatan Penanganan Covid-19.

Badan Pusat Statistik Kabupaten Pandeglang. (2018). Kecamatan Majasari dalam Angka.

Badan Pusat Statistik Kabupaten Pandeglang. (2018). Statistik Kesejahteraan Rakyat Kabupaten Pandeglang 